\title{
SEASONALITY AND HOST PREFERENCE OF ARBUSCULAR MYCORRHIZAL FUNGI OF FIVE PLANT SPECIES IN THE INNER MONGOLIA STEPPE, CHINA
}

\section{Yuan-Ying Su${ }^{1,2}, X_{i n} \operatorname{Sun}^{1,2}$, Liang-Dong Guo ${ }^{1 *}$}

${ }^{1}$ Systematic Mycology and Lichenology Laboratory, Institute of Microbiology, Chinese Academy of Sciences, Beijing 100101, People's Republic of China; ${ }^{2}$ Graduate University of Chinese Academy of Sciences, Beijing 100049, People's Republic of China.

Submitted: February 10, 2010; Approved: August 28, 2010.

\begin{abstract}
The seasonal change and host preference of arbuscular mycorrhizal (AM) colonization and community composition of five common plant species Agropyron cristatum, Anemarrhena asphodeloides, Cleistogenes squarrosa, Leymus chinensis, and Stipa grandis in the Inner Mongolia steppe were investigated. The AM root length colonization rates were different among the five plant species and were generally high in early (May and June) and late (September) growth seasons and low in August. A total of 18 AM fungal species representing five genera were isolated from rhizosphere soils of the five plant species, and most AM fungi had not host specificity, except that Acaulospora sp., Glomus constrictum, G. diaphanum and Glomus sp. showed a certain degree of host preference. Glomus albidum, G. etunicatum and G. geosporum were the dominant species and showed various sporulation patterns in the five plants during the growth seasons. The AM fungal spore densities and species richness increased from May to September and decreased in October and were different in the same month in the five plants. Multivariate analyses revealed that season and host significantly co-affected the AM fungal spore density, species richness, and Shannon-Wiener diversity index, and the season had higher influence than the host.
\end{abstract}

Key words: seasonal dynamics, arbuscular mycorrhizal fungi, diversity, grassland

\section{INTRODUTION}

Arbuscular mycorrhizal (AM) fungi are widely distributed and form mutualistic symbioses with most vascular plants in grassland ecosystems (40). AM fungi comprise the largest component (mycelia and spores) of the microbial biomass in soil $(14,30,32)$ and can increase plant nutrient and water uptake, particularly in nutrient poor soil of arid and semiarid ecosystems $(1,8,10,22,24)$. AM fungi therefore play an important ecological role in determining the plant diversity, productivity, and species composition in terrestrial ecosystems (26, 43, 44, 45). Mycorrhizal dynamics and host specificity provides insights into the factors and processes regulating ecosystem development. Therefore, understanding how the dynamics and host specificity of AM fungal communities in colonization, composition, and diversity are key to understanding the ecology and function of fungus-plant association in natural ecosystems. 
Previous studies of AM fungal dynamics have yielded conflicting results. For examples, some studies indicated that maximal AM fungal spore densities were found in the end growth season (Autumn) of five grasses in mountain grassland of Argentina (28), of Schizachyrium scoparium (Michx.) Nash in sand prairies in Illinois (12), and in sand dune in Dartmouth of Massachusetts (17). Yet the highest AM fungal spore densities were reported in summer of Spartina ciliate Brongn. in the island of Santa Catarina (41), of Lotus glaber Mill. in temperate grasslands of Argentina (15), and of two fruit species (Theobroma grandiflorum Schum. and Paullinia cupana var. sorbilis Mart.) in a terra firme ecosystem in Central Amazonia (33). Therefore, the seasonal dynamics of AM fungal sporulation need further to be documented.

Most previous studies indicated that AM fungi had not host specificity $(9,36,40)$. However, some studies showed that the sporulation and community compositions of AM fungi have been found to be host dependent $(6,28)$. For examples, Bentivenga and Hetrick (4) found that sporulation of AM fungi was influenced by hosts in tallgrass prairie grasses. Li et al. (27) investigated three plants in a hot and arid ecosystem of southwest China, and the results indicated that the sporulation and community compositions of AM fungi were different. Therefore, host specificity of AM fungi, which may play an important role in the maintenance of plant diversity in natural ecosystems, need further to be studied.

Inner Mongolia steppe, distributed at the eastern end of Eurasian steppe zone, is the largest grassland in China and is an important natural resource in arid and semiarid regions, which significantly contributes to the Chinese economy and ecology. In recent years, severe degradation and desertification were found due to intense human activities such as grazing, mowing, and crop cultivation in grassland. Many ecological studies concerning animals and plants have been carried out in this ecosystem (e.g., 2, 21). However, AM fungi, which have an important ecological function in grassland ecosystems, have not been studied in seasonal dynamics and host specificity in the Inner Mongolia steppe, except that the response of AM fungi to non-grazed, restored, and over-grazed was investigated
(42).

Agropyron cristatum (L.) Gaertn., Anemarrhena asphodeloides Bunge, Cleistogenes squarrosa (Trin.) Keng, Leymus chinensis (Trin.) Tzvel., and Stipa grandis P. Smirn. are the most common plant species, which are highly important nutritional forage value for sheep and cattle in the Inner Mongolia steppe. This study focused on these five common plant species in this grassland. The basic aims were 1) to investigate the seasonal changes of AM fungal colonization, sporulation, species composition, and diversity and 2) to understand whether there was host preference of AM fungi in the five common plant species in the Inner Mongolia steppe.

\section{MATERIALS AND METHODS}

\section{Study site}

This study was conducted in the Inner Mongolia Grassland Ecosystem Research Station, the Chinese Academy of Sciences $\left(43^{\circ} 26^{\prime}-44^{\circ} 08^{\prime} \mathrm{N}, 116^{\circ} 04^{\prime}-117^{\circ} 05^{\prime} \mathrm{E}\right)$, located in typical steppe zone of the Inner Mongolia Plateau. The area has a semiarid continental temperate steppe climate with a dry spring and moist summer. Annual mean temperature is $2{ }^{\circ} \mathrm{C}$, and annual precipitation is $350 \mathrm{~mm}$. The soil water content of sampling time was listed in Figure 1.

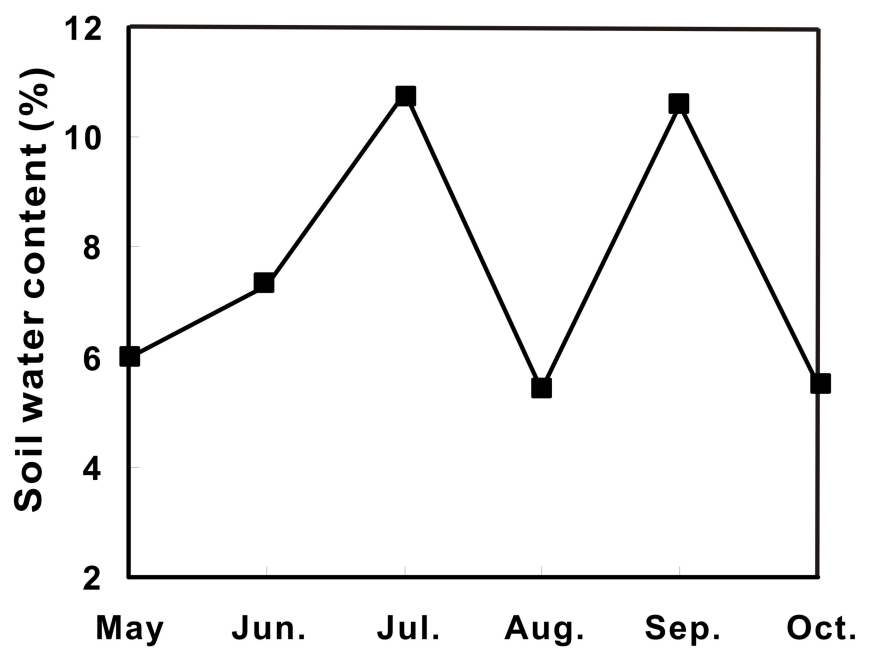

Figure 1. The soil water content of the six sampling months. 
A permanent plot (ca. $500 \mathrm{~m} \times 500 \mathrm{~m}$ ), which has been fenced since 1979, was selected in this study. There are about 30 plant species in the plot, and five dominant plants, such as $S$. grandis, A. cristatum, A. asphodeloides, $C$. squarrosa, and $L$. chinensis, were chosen for the present study. These five plants begin growing in early May and end growth in October, and produce seeds in late August. Ten subplots $(1 \mathrm{~m} \times 1 \mathrm{~m})$ of each plant species were randomly established and were more than $10 \mathrm{~m}$ away from each other.

\section{Sampling procedure}

Sampling was carried out at the beginning of each month from May to October 2006. On each sampling date, three sample cores $(5 \mathrm{~cm}$ diam $\times 15 \mathrm{~cm}$ deep) were randomly taken in each subplot. The three soil samples from rhizospheres of the same plant species along with the roots were placed in the sterilized cotton-cloth bag and labeled as one representative sample. The root systems were separated from the soil samples and processed within one day in the laboratory. The soil samples were air dried in the shade for one week. Then they were sifted with a $2 \mathrm{~mm}$ sieve, stored at $4^{\circ} \mathrm{C}$, and processed within 3 months.

\section{AM structure and colonization}

Root (0.2 g) of each sample was rinsed with tap water, cleared in $10 \%(\mathrm{w} / \mathrm{v})$ potassium hydroxide $\left(20-50 \mathrm{~min}, 92^{\circ} \mathrm{C}\right)$, acidified in lactic acid $(3 \mathrm{~min})$, and stained $\left(20 \mathrm{~min}, 92^{\circ} \mathrm{C}\right)$ with $0.5 \%$ acid fuchsin (5). A total of 50 root fragments (ca. $1-\mathrm{cm}$ long) from each plant were mounted on slides in a polyvinyl alcohol-lactic acid-glycerol solution and examined with a compound microscope (Olympus BH-2) at $\times 100-400$ to ascertain the presence of AM fungal structures, i.e. arbuscules, vesicles, hyphal coils, and non-septate hyphae. The percentage of root length colonized by AM fungal structures was determined using the following formula: \%Colonization rate = (total length of root segments colonized / total length of root segments examined) $\times 100$.

\section{Spore isolation and identification of AM fungi}

Fifty grams of each air-dried soil sample was used for spore isolation. AM fungal spores were isolated using the wetsieving and decanting method of Gerdemann and Nicolson (19), modified by Daniels and Skipper (11). AM fungi were identified following the descriptions of Schenck and Pérez (37), the information on the International Culture Collection of Arbuscular and Vesicular-Arbuscular Mycorrhizal Fungi on the internet (www.invam.caf.wdu.edu) and the original species descriptions with their corrections. Spores were first mounted in water and morphological characteristics were measured. Melzer's reagent and cotton blue were also used in the identification. The permanent slides were mounted in polyvinyl-lacto-glycerol, sealed with nail varnish, and stored in the Herbarium Mycologicum Academiae Sinicae in Institute of Microbiology, Chinese Academy of Sciences, Beijing, China.

\section{Data analysis}

Spore density (spores per $50 \mathrm{~g}$ air-dried soil) was calculated from direct counts of spores. Species richness was defined as the number of AM fungal species per soil sample (25). Shannon-Weiner diversity index ( $\left.H^{\prime}\right)$ was calculated according to the formula: $H^{\prime}=-\sum_{i=1}^{s} p_{i} \times \ln p_{i}$, where $S$ is the number of species in the sample, and $P_{i}$ is the relative abundance of AM fungus species of one site (38).

Data on AM colonization rate, spore density, and species richness were analyzed using one-way analysis of variance (ANOVA) to determine any significant difference (SPSS for windows, version 11.5, SPSS Inc, Chicago, USA). Data on season and host co-affect on the AM fungal spore density, species richness, and Shannon-Wiener diversity index were analyzed using multivariate analysis of variance. The statistically significant difference was determined at $p<0.05$ level.

\section{RESULTS}

\section{AM colonization rate}

AM colonization rates were generally high in May, June, and September and low in August in the five plant species, except for a lower AM colonization rate in S. grandis in 
September (Table 1). There were significantly higher overall root colonization rates of AM fungi in A. cristatum, $L$. chinensis and $S$. grandis than in A. asphodeloides and $C$. squarrosa, but no significant difference between $L$. chinensis and $S$. grandis and between A. asphodeloides and C. squarrosa (Table 1).

\section{AM fungal composition}

A total of 18 AM fungi belonging to five genera were identified (Table 2). Of these one belonged to Acaulospora, one to Archaeospora, one to Entrophospora, 14 to Glomus, and one to Scutellospora. Glomus albidum, G. etunicatum and $G$. geosporum were the dominant species in the five plant species.

There were 15, 16, 16, 15, and 14 AM fungal species isolated from A. cristatum, A. asphodeloides, C. squarrosa, $L$. chinensis, and S. grandis, respectively, and most AM fungi had not host specificity (Table 2). However, Glomus constrictum was only associated with A. cristatum. Acaulospora sp. occurred in C. squarrosa and S. grandis. Glomus sp. 1 was isolated from A. cristatum and A. asphodeloides. Glomus diaphanum was found in A. asphodeloides, C. squarrosa, and L. chinensis.

Table 1. The root length colonization rate (CR), spore density (SD) and species richness (SR) of AM fungi in the five plant species in different months.

\begin{tabular}{|c|c|c|c|c|c|c|c|c|}
\hline Plant & & May & Jun. & Jul. & Aug. & Sep. & Oct. & Overall \\
\hline \multirow{3}{*}{$\begin{array}{l}\text { Agropyron } \\
\text { cristatum }\end{array}$} & $\mathrm{CR}$ & $55.6 \pm 5.5 \mathrm{abAB}$ & $58.7 \pm 3.4 \mathrm{bA}$ & $47.1 \pm 4.2 \mathrm{acAC}$ & $39.5 \pm 2.0 \mathrm{cAC}$ & $61.6 \pm 3.4 \mathrm{bA}$ & $40.7 \pm 3.7 \mathrm{cA}$ & $50.6 \pm 1.9 \mathrm{~A}$ \\
\hline & SD & $22.8 \pm 1.2 \mathrm{aA}$ & $38.1 \pm 5.5 \mathrm{bAB}$ & $39.5 \pm 3.2 \mathrm{bA}$ & $74.6 \pm 6.1 \mathrm{cAB}$ & $93.8 \pm 3.5 \mathrm{dA}$ & $47.5 \pm 5.8 \mathrm{bAC}$ & $54.4 \pm 3.7 \mathrm{AB}$ \\
\hline & SR & $1.9 \pm 0.2 \mathrm{aA}$ & $2.4 \pm 0.4 \mathrm{abA}$ & $3.1 \pm 0.4 \mathrm{bA}$ & $5.1 \pm 0.3 \mathrm{cA}$ & $5.1 \pm 0.3 \mathrm{cA}$ & $4.4 \pm 0.5 \mathrm{cA}$ & $3.6 \pm 0.2 \mathrm{~A}$ \\
\hline \multirow{3}{*}{$\begin{array}{l}\text { Anemarrhena } \\
\text { asphodeloides }\end{array}$} & $\mathrm{CR}$ & $41.4 \pm 5.3 \mathrm{abAC}$ & $44.2 \pm 6.1 \mathrm{bB}$ & $30.3 \pm 3.2 \mathrm{acB}$ & $20.9 \pm 3.3 \mathrm{cB}$ & $41.7 \pm 2.3 \mathrm{abBC}$ & $31.4 \pm 3.5 \mathrm{acA}$ & $34.8 \pm 1.9 \mathrm{~B}$ \\
\hline & SD & $35.3 \pm 7.3 \mathrm{aB}$ & $40.2 \pm 5.9 \mathrm{aA}$ & $44.8 \pm 6.6 \mathrm{acA}$ & $77.8 \pm 9.2 \mathrm{bdB}$ & $94.9 \pm 8.3 \mathrm{dA}$ & $64.7 \pm 6.1 \mathrm{bcBC}$ & $62.1 \pm 4.9 \mathrm{~A}$ \\
\hline & SR & $2.4 \pm 0.2 \mathrm{aA}$ & $2.7 \pm 0.3 \mathrm{aA}$ & $2.7 \pm 0.4 \mathrm{aB}$ & $5.1 \pm 0.2 \mathrm{bA}$ & $5.2 \pm 0.2 \mathrm{bA}$ & $4.3 \pm 0.2 \mathrm{cA}$ & $3.7 \pm 0.2 \mathrm{~A}$ \\
\hline Cleistogenes & $\mathrm{CR}$ & $37.9 \pm 0.6 \mathrm{abA}$ & $45.4 \pm 1.7 \mathrm{aB}$ & $36.7 \pm 2.7 \mathrm{abB}$ & $32.5 \pm 3.3 \mathrm{bA}$ & $37.7 \pm 2.6 \mathrm{abB}$ & $41.5 \pm 4.7 \mathrm{abA}$ & $38.6 \pm 1.5 \mathrm{~B}$ \\
\hline \multirow[t]{2}{*}{ squarrosa } & SD & $30.6 \pm 4.0 \mathrm{aA}$ & $28.7 \pm 4.5 \mathrm{aAB}$ & $37.7 \pm 3.8 \mathrm{abA}$ & $47.3 \pm 4.7 \mathrm{bC}$ & $97.1 \pm 10.5 \mathrm{cA}$ & $36.7 \pm 3.7 \mathrm{abA}$ & $46.6 \pm 3.8 \mathrm{~B}$ \\
\hline & SR & $3.5 \pm 0.4 \mathrm{abB}$ & $2.6 \pm 0.5 \mathrm{aA}$ & $3.4 \pm 0.5 \mathrm{ab} \mathrm{AB}$ & $4.2 \pm 0.4 \mathrm{bcA}$ & $5.2 \pm 0.2 \mathrm{cA}$ & $4.2 \pm 0.3 \mathrm{bcA}$ & $3.9 \pm 0.2 \mathrm{~A}$ \\
\hline \multirow[t]{3}{*}{ Leymus chinensis } & $\mathrm{CR}$ & $59.0 \pm 8.5 \mathrm{aBC}$ & $71.7 \pm 3.2 \mathrm{aC}$ & $62.3 \pm 3.8 \mathrm{aC}$ & $37.6 \pm 3.2 \mathrm{bA}$ & $63.2 \pm 3.8 \mathrm{aA}$ & $38.0 \pm 3.7 \mathrm{bA}$ & $54.9 \pm 2.8 \mathrm{AC}$ \\
\hline & SD & $11.0 \pm 1.7 \mathrm{aC}$ & $26.1 \pm 3.3 \mathrm{aB}$ & $54.3 \pm 9.5 \mathrm{bAB}$ & $51.6 \pm 4.7 \mathrm{bC}$ & $71.7 \pm 5.8 \mathrm{cB}$ & $52.0 \pm 5.0 \mathrm{bBC}$ & $45.9 \pm 3.6 \mathrm{~B}$ \\
\hline & SR & $2.0 \pm 0.3 \mathrm{aA}$ & $2.6 \pm 0.3 \mathrm{aA}$ & $3.9 \pm 0.3 \mathrm{bA}$ & $4.3 \pm 0.3 \mathrm{bcA}$ & $5.0 \pm 0.1 \mathrm{cA}$ & $4.5 \pm 0.3 \mathrm{bcA}$ & $3.7 \pm 0.2 \mathrm{~A}$ \\
\hline \multirow[t]{3}{*}{ Stipa grandis } & $\mathrm{CR}$ & $63.9 \pm 5.5 \mathrm{abB}$ & $72.7 \pm 4.0 \mathrm{bC}$ & $55.1 \pm 2.5 \mathrm{acC}$ & $46.2 \pm 2.9 \mathrm{cC}$ & $46.6 \pm 1.8 \mathrm{cC}$ & $56.0 \pm 3.4 \mathrm{acB}$ & $56.8 \pm 1.8 \mathrm{C}$ \\
\hline & SD & $22.8 \pm 3.1 \mathrm{aA}$ & $28.1 \pm 1.8 \mathrm{aAB}$ & $71.3 \pm 8.5 \mathrm{bB}$ & $59.7 \pm 5.0 \mathrm{bdAC}$ & $91.9 \pm 7.4 \mathrm{cAB}$ & $50.8 \pm 3.9 \mathrm{dABC}$ & $54.3 \pm 3.8 \mathrm{AB}$ \\
\hline & SR & $2.2 \pm 0.2 \mathrm{aA}$ & $2.2 \pm 0.2 \mathrm{aA}$ & $4.9 \pm 0.1 \mathrm{bC}$ & $4.8 \pm 0.3 \mathrm{bA}$ & $5.0 \pm 0.2 \mathrm{bA}$ & $4.6 \pm 0.2 \mathrm{bA}$ & $4 \pm 0.2 \mathrm{~A}$ \\
\hline
\end{tabular}

Values within the same row followed by the same lower case letter were not significantly different between months in each host, and values within the same column followed by the same capital letter were not significantly different between hosts in each month $(\mathrm{mean} \pm \mathrm{SE}, \mathrm{n}=10$ in each month, $\mathrm{n}=60$ in overall, $\mathrm{p}<0.05$ ). 
Table 2. Overall mean spore densities of AM fungi in the five plant species (mean $\pm S E, n=60$ ).

\begin{tabular}{|c|c|c|c|c|c|}
\hline AM fungus & $\begin{array}{c}\text { Agropyron } \\
\text { cristatum }\end{array}$ & $\begin{array}{l}\text { Anemarrhena } \\
\text { asphodeloides }\end{array}$ & $\begin{array}{c}\text { Cleistogenes } \\
\text { squarrosa }\end{array}$ & $\begin{array}{c}\text { Leymus } \\
\text { chinensis }\end{array}$ & $\begin{array}{c}\text { Stipa } \\
\text { grandis }\end{array}$ \\
\hline Acaulospora sp. & 0 & 0 & $0.05 \pm 0.05$ & 0a & $0.2 \pm 0.1$ \\
\hline Archaeospora trappei (R.N. Ames \& Linderman) J.B. Morton \& & $0.2 \pm 0.2$ & $0.1 \pm 0.1$ & $0.1 \pm 0.1$ & $0.03 \pm 0.03$ & 0 \\
\hline \multicolumn{6}{|l|}{ D. Redecker } \\
\hline Entrophospora infrequens (I.R. Hall) R.N. Ames \& R.W. Schneid. & $0.03 \pm 0.03$ & $0.03 \pm 0.03$ & $0.05 \pm 0.05$ & $0.08 \pm 0.06$ & $0.05 \pm 0.05$ \\
\hline Glomus aggregatum N.C. Schenck \& G.S. Sm. & $4.4 \pm 0.8$ & $1.8 \pm 0.5$ & $2.6 \pm 0.8$ & $2.0 \pm 0.5$ & $2.1 \pm 0.6$ \\
\hline G. albidum C. Walker \& L.H. Rhodes & $7.5 \pm 0.9$ & $9.8 \pm 1.3$ & $5.5 \pm 1.3$ & $4.7 \pm 0.7$ & $9.6 \pm 1.0$ \\
\hline G. ambisporum G.S. Sm. \& N.C. Schenck & $1.2 \pm 0.4$ & $0.7 \pm 0.2$ & $1.8 \pm 0.5$ & $1.6 \pm 0.6$ & $1.3 \pm 0.4$ \\
\hline G. constrictum Trappe & $0.1 \pm 0.04$ & 0 & 0 & 0 & 0 \\
\hline G. diaphanum J.B. Morton \& C. Walker & 0 & $1.8 \pm 0.8$ & $0.4 \pm 0.3$ & $1.0 \pm 0.4$ & 0 \\
\hline G. etunicatum W.N. Becker \& Gerd. & $20.3 \pm 1.3$ & $16.3 \pm 2.0$ & $19.9 \pm 2.0$ & $18.0 \pm 2.0$ & $17.0 \pm 1.1$ \\
\hline G. fasciculatum (Thaxt.) Gerd. \& Trappe & 0 & $0.2 \pm 0.2$ & $0.3 \pm 0.2$ & $0.4 \pm 0.2$ & $0.3 \pm 0.2$ \\
\hline HG. fistulosumH Skou \& I. Jakobsen & $0.5 \pm 0.3$ & $0.5 \pm 0.3$ & $0.2 \pm 0.2$ & $0.7 \pm 0.4$ & $0.1 \pm 0.1$ \\
\hline G. geosporum (T.H. Nicolson \& Gerd.) C. Walker & $16.1 \pm 1.8$ & $19.3 \pm 1.7$ & $12.9 \pm 1.3$ & $13.3 \pm 1.3$ & $21.1 \pm 2.1$ \\
\hline G. intraradices N.C. Schenck \& G.S. Sm. & $0.3 \pm 0.1$ & $1.0 \pm 0.5$ & $0.1 \pm 0.1$ & $0.3 \pm 0.2$ & $0.3 \pm 0.1$ \\
\hline G. microcarpum Tul. \& C. Tul. & $0.7 \pm 0.4$ & $1.8 \pm 1.2$ & $0.03 \pm 0.03$ & $0.4 \pm 0.2$ & $0.08 \pm 0.08$ \\
\hline G. mosseae (T.H. Nicolson \& Gerd.) Gerd. \& Trappe & $0.5 \pm 0.2$ & $0.08 \pm 0.08$ & $0.7 \pm 0.2$ & $0.3 \pm 0.2$ & $0.6 \pm 0.2$ \\
\hline Glomus sp.1 & $0.2 \pm 0.2$ & $4.9 \pm 1.5$ & 0 & 0 & 0 \\
\hline Glomus sp. 2 & $0.1 \pm 0.1$ & $0.08 \pm 0.08$ & $0.8 \pm 0.3$ & $0.3 \pm 0.2$ & $0.08 \pm 0.08$ \\
\hline Scutellospora calospora (T.H. Nicolson \& Gerd.) C. Walker \& & $0.9 \pm 0.2$ & $1.0 \pm 0.2$ & $1.0 \pm 0.1$ & $1.3 \pm 0.2$ & $1.3 \pm 0.2$ \\
\hline F.E. Sanders & & & & & \\
\hline
\end{tabular}

\section{AM fungal spore density, species richness and diversity}

The AM fungal spore densities and species richness increased from May to September and decreased in October in the five plant species (Table 1). The spore densities of the three dominant species G. albidum, G. etunicatum and G. geosporum had a similar trend, except that G. albidum peaked in August in $S$. grandis and G. etunicatum peaked in July in L. chinensis (Figure 2). $G$. albidum had lower spore density than $G$. geosporum and $G$. etunicatum in the five plant species. Furthermore, there were the highest spore densities of $G$. etunicatum in C. squarrosa and L. chinensis and G. geosporum in $S$. grandis.

The spore densities of AM fungi were often significantly different in the same month among the five plant species (Table 1). Whereas, AM fungal species richness were not significantly different in the same month, except that the species richness were significantly higher in $C$. squarrosa than in the other four plant species in May and in S. grandis than in the other four plant species and in A. cristatum and L. chinensis than in A. asphodeloides in July.

There was no significant difference of the overall spore densities of AM fungi among the five plant species, except for a significantly higher spore density in A. asphodeloides than in L. chinensis and C. squarrosa (Table 1). The overall species richness of AM fungi was not significantly different among the five plants (Table 1).

Multivariate analysis revealed that seasons and hosts significantly co-affected the AM fungal spore density, species richness, and Shannon-Wiener diversity index, and the seasons had higher influence than hosts based on the analyses of $\mathrm{F}$ values (Table 3 ). 


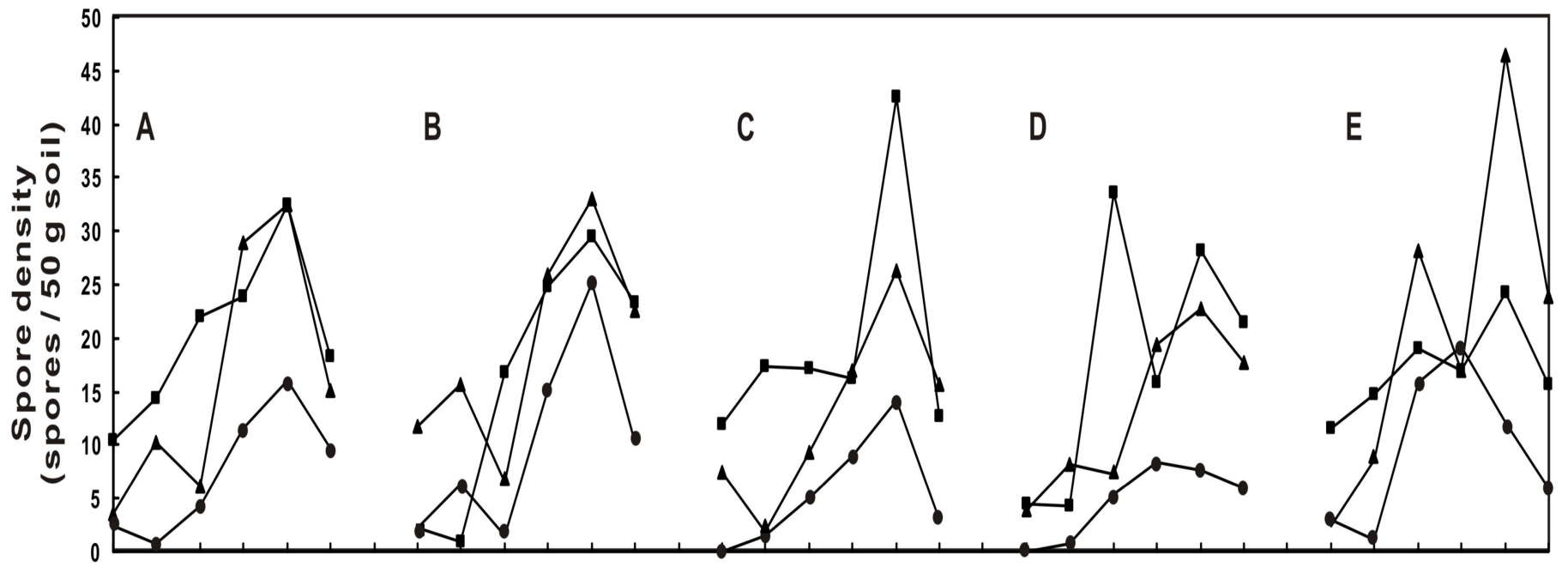

May Jun. Jul. Aug.Sep. Oct. May Jun. Jul. Aug. Sep. Oct. May Jun. Jul. Aug. Sep. Oct. May Jun. Jul. Aug. Sep. Oct. May Jun. Jul. Aug. Sep. Oct.

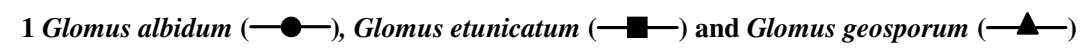

Figure 2. The seasonal dynamics of the spore densities of the dominant species Glomus albidum (一-), Glomus etunicatum (一-) and Glomus geosporum (——) in plants Agropyron asphodeloides (A), Anemarrhena cristatum (B), Cleistogenes squarrosa (C), Leymus chinensis (D), and Stipa grandis $(\mathrm{E})$.

Table 3. The effect of season and host on the AM fungal spore density (SD), species richness (SR), Shannon-Wiener diversity index $(\mathrm{H})$.

\begin{tabular}{lcccccc}
\hline & \multicolumn{2}{c}{ SD } & \multicolumn{2}{c}{ SR } & \multicolumn{2}{c}{ H } \\
& $\boldsymbol{F}$ & $\boldsymbol{p}$ & $\boldsymbol{F}$ & $\boldsymbol{p}$ & $\boldsymbol{F}$ & $\boldsymbol{p}$ \\
\hline Season & 80.174 & $<0.001$ & 67.256 & $<0.001$ & 46.444 & $<0.001$ \\
Host & 6.714 & $<0.001$ & 1.019 & 0.398 & 0.599 & 0.664 \\
Season $\times$ Host & 2.878 & $<0.001$ & 2.709 & $<0.001$ & 2.334 & $<0.001$ \\
& & & & & & \\
\hline
\end{tabular}

\section{DISCUSSION}

\section{Effect of season and host on AM colonization rate}

The root length colonization rates of AM fungi were generally high in early (May and June) and late (September) growth seasons in the five plant species in the present study. Similar results of the highest AM colonization rates in early and late growth seasons were found in Agropyron smithii Rydb., Poa pratensis L., and Bromus inermis Leyss. in tallgrass prairie grasses (4) and in Ammophila arenaria (L.)
Link. in six locations of the European coast (35). This is because the plants grow fast in early growth season and produce seeds in the late growth season, and there were high metabolic activities and nutrient demands of the plants during these seasons $(31,32)$. The AM structures, i.e., arbuscules, hyphal coils and vesicles, are the sites of storage and exchanging nutrients between fungi and hosts (4, 39), therefore, there were high AM colonization rates in these growth seasons.

Our results indicated that all the five plants had the lowest 
AM root length colonization rates in August. The possible reason is that the soil water content was much lower in August than in the other months in the Inner Mongolia steppe (Figure 1), as results were reported by Oliveira and Oliveira (33), which soil water content affected AM fungal sporulation.

There were different overall AM root colonization rates in the five plant species. Similarly, Lugo et al. (29) found that the $\mathrm{AM}$ root colonization rates of six hosts were different, and the root length colonization rate of AM fungi was significantly higher in Sorghastrum pellitum (Hack.) Parodi than in the other five plant species in a mountain grassland. In the study of Li et al. (27), the total colonization rates of three plants Bothriochloa pertusa (L.) A. Camus, Cajanus cajan (L.) Millsp., and Heteropogon contortus (L.) P. Beauv. ex Roem. et Schult. were different in a hot and arid ecosystem of southwest China. It is highly possible that the plant characters and the host preference of AM fungi co-affected the AM colonization $(16,29)$.

\section{Effect of season and host on AM fungi}

The AM fungal spore densities and species richness increased with plant growth and reached the highest numbers in late growth season (September) in the five plant species. Similar results have been reported in previous studies $(12,18)$. For examples, Bentivenga and Hetrick (4) found that AM fungal spore densities increased with plant growth and reached the highest numbers in late growth seasons (October and November) in A. smithii, $P$. pratensis, and $B$. inermis in tallgrass prairie grasses. The spore numbers were significantly higher in the late growth season (October) than in the early growth seasons (April and July) of A. arenaria in Netherlands, United Kingdom England, and United Kingdom Wales (35).

However, our results indicated that the three dominant species had different sporulation patterns during the growth seasons. Similarly, Lugo and Cabello (28) found that Acaulospora mellea Spain \& N.C. Schenck had the highest spore density in spring, but Glomus spp. reached the highest spore numbers in autumn in Eragrostis lugens Nees, Poa stuckertii (Hack.) Parodi, and S. pellitum in mountain grassland of Argentina. This is because the maximal sporulation and diversity occurred near the end of the host growing cycle or reproductive cycle for survival in following cold stage, while individual species of AM fungi show varying patterns of spore abundance in relation to plant growth seasons $(12,13,18,35)$.

The overall spore densities of AM fungi differed among the five plant species. Eom et al. (13) found that the spore densities were different from 15.94 to 61.45 per $1 \mathrm{~g}$ soil in hosts $P$. pratensis, Sporobolus heterolepis (A. Gray) A. Gray, Panicum virgatum L., Baptisia bracteata Muhl. ex Ell., and Solidago missouriensis Nutt. in a tallgrass prairie. Furthermore, Acaulospora longula Spain \& N.C. Schenck was the most abundant under stands of S. missouriensis, but Glomus rubiformis (Gerd. \& Trappe) Almeida \& Schenck and $G$. aggregatum were most abundant under S. heterolepis. The number of spores of Glomus white reduced when Archaeospora trappei and Scutellospora calospora appeared in Plantago lanceolata L. (3). Similarly, our study indicated that the three dominant species had different sporulation in the five plants. G. albidum had lower spore density than G. geosporum and G. etunicatum in the five plant species, and G. etunicatum produced the maximal spores in C. squarrosa and L. chinensis and G. geosporum in S. grandis. AM fungal sporulation can be influenced by host plants, and has competition in the community for host resources and for defence themselves from stress $(3,7,13,34)$.

Our results indicated that AM fungal composition was similar in the five plants and the most AM fungi had not host specificity. However, species Acaulospora sp., G. constrictum, G. diaphanum and Glomus sp. 1 showed a certain degree of host preference. Similarly, Lugo and Cabello (28) found that Glomus fuegianum (Speg.) Trappe \& Gerd. occurred in Briza subaristata Lam. and P. stuckertii, but Glomus sp. 3 was only associated with $P$. stuckertii. Li et al. (27) analyzed the AM fungal composition of plants B. pertusa, C. cajan, and $H$. contortus using molecular method, and the results demonstrated that AM fungi had strong host preference. Similar results were also reported in other studies, in which different plant species were associated with divergent AM 
fungal communities $(13,20)$.

Season and host significantly co-affected the spore density, species richness, and Shannon-Wiener diversity index of AM fungi in our study. The season and host are the most important factors influenced AM fungal sporulation and species diversity in natural ecosystems, because host plants can regulate carbon allocation to roots, produce secondary metabolites, and change soil environmental conditions during growth seasons. However, the ecological function of AM fungi in regulating plant ecosystem development and restoring degraded ecosystem needs further to study in the Inner Mongolia steppe.

\section{ACKNOWLEGEMENTS}

The authors are grateful to the Inner Mongolia Grassland Ecosystem Research Station of the Chinese Academy of Sciences for their help when sampling. This work was supported by the National Natural Science Foundation of China Grants (30930005, 30870087 and 30499340).

\section{REFERENCES}

1. Allen, M.F. (1982). Influence of vesicular-arbuscular mycorrhizae on water movement through Bouteloua gracilis (H.B.K.) Lag ex Steul. New Phytol. 91, 191-196.

2. Bai, Y.F; Han, X.G.; Wu, J.G.; Chen, Z.Z.; Li, L.H. (2004). Ecosystem stability and compensatory effects in the Inner Mongolia grassland. Nature 431 (9), 181-184.

3. Bennett, A.E.; Bever, J.D. (2009). Trade-offs between arbuscular mycorrhizal fungal competitive ability and host growth promotion in Plantago lanceolata. Oecologia 160 (4), 807-816.

4. Bentivenga, S.P.; Hetrick, B.A.D. (1992). Seasonal and temperature effects on mycorrhizal activity and dependence of cool- and warm-season tallgrass prairie grasses. Can. J. Bot. 70 (8), 1596-1602.

5. Berch, S.M.; Kendrick, B. (1982). Vesicular-arbuscular mycorrhizae of southern Ontario ferns and fern-allies. Mycologia 74 (5), 769-776.

6. Bever, J.D.; Morton, J.B.; Antonovics, J. Schultz, P.A. (1996). Hostdependent sporulation and diversity of arbuscular mycorrhizal fungi in a mown grassland. J. Ecol. 84, 71-82.

7. Cano, C.; Bago, A. (2005). Competition and substrate colonization strategies of three polyxenically grown arbuscular mycorrhizal fungi. Mycologia 97 (6), 1201-1214.
8. Caravaca, F.; Alguacil, M.M.; Díaz, G.; Marín, P.; Roldán, A. (2005). Nutrient acquisition and nitrate reductase activity of mycorrhizal Retama sphaerocarpa L. seedlings afforested in an amended semiarid soil under two water regimes. Soil Use Manage. 21 (1), 10-16.

9. Clapp, J.P.; Young, J.P.W.; Merryweather, J.W.; Fitter, A.H. (1995). Diversity of fungal symbionts in arbuscular mycorrhizas from a natural community. New Phytol. 130 (2), 259-265.

10. Cui, M.; Nobel, P.S. (1992). Nutrient status, water uptake and gas exchange for three desert succulents infected with mycorrhizal fungi. New Phytol. 122 (4), 643-649.

11. Daniels, H.B.A.; Skipper, H.D. (1982). Methods for the recovery and quantitative estimation of propagules from soil. In: Schenck, N.C. (ed). Method and Principles of Mycorrhiza Research. American Society for Phytopathology, St. Paul. Minn. p.29-37.

12. Dhillion, S.S.; Anderson, R.C. (1993). Seasonal dynamics of dominant species of arbuscular mycorrhizae in burned and unburned sand prairies. Can. J. Bot. 71 (12), 1625-1630.

13. Eom, A.H.; Hartnett, D.C.; Wilson, G.W.T. (2000). Host plant species effects on arbuscular mycorrhizal fungal communities in tallgrass prairie. Oecologia 122, 435-444.

14. Eriksen, M.; Bjureke, K.E.; Dhillion, S.S. (2002). Mycorrhizal plants of traditionally managed boreal grasslands in Norway. Mycorrhiza 12 (3), 117-123.

15. Escudero, V.; Mendoza, R. (2005). Seasonal variation of arbuscular mycorrhizal fungi in temperature grassland along a wide hydrologic gradient. Mycorrhiza 15 (4), 291-299.

16. Fisher, J.B.; Jayachandran, K. (1999). Root structure and arbuscular mycorrhizal colonization of the palm Serenoa repens under field conditions. Plant Soil 217, 229-241.

17. Gemma, J.N.; Koske, R.E.; Carreiro, M. (1989). Seasonal dynamics of selected species of VA-mycorrhizal fungi in a sand dune. Mycol. Res. 92 (3), 317-321.

18. Gemma, J.N.; Koske, R.E. (1988). Seasonal variation in spore abundance and dormancy of Gigaspora gigantea and in mycorrhizal inoculum potential of a dune soil. Mycologia 80, 211-216.

19. Gerdemann, J.W.; Nicolson, T.H. (1963). Spores of mycorrhizal Endogone species extracted from soil by wet sieving and decanting. Trans. Br. Mycol. Soc. 46, 235-244.

20. Gollotte, A.; van Tuinen D.; Atkinson, D. (2004). Diversity of arbuscular mycorrhizal fungi colonising roots of the grass species Agrostis capillaris and Lolium perenne in a field experiment. Mycorrhiza 14 (2), 111-117.

21. Kang, L.; Chen, Y.L. (1995). Dynamics of grasshopper communities under different grazing intensities in Inner Mongolian steppes. Entomol. Sin. 2, 265-281.

22. Khalvati, M.; Bartha, B.; Dupigny, A.; Schröder, P. (2010). Arbuscular mycorrhizal association is beneficial for growth and detoxification of xenobiotics of barley under drought stress. J. Soils Sediments 10 (1), 5464.

23. Koide, R.T.; Huenneke, L.F.; Hamburg, S.P.; Mooney, H.A. (1988). 
Effects of applications of fungicide, phosphorus and nitrogen on the structure and productivity of an annual serpentine plant community. Funct. Ecol. 2, 335-344.

24. Koide, R.T. (1991). Nutrient supply, nutrient demand and plant response to mycorrhizal infection. New Phytol. 111, 35-44.

25. Koske, R.E. (1987). Distribution of VA mycorrhizal fungi along a latitudinal temperature gradient. Mycologia 79, 55-68.

26. Leigh, J.; Hodge, A.; Fitter, A.H. (2009). Arbuscular mycorrhizal fungi can transfer substantial amounts of nitrogen to their host plant from organic material. New Phytol. 181, 199-207.

27. Li, L.F.; Li, T.; Zhang, Y.; Zhao, Z.W. (2010). Molecular diversity of arbuscular mycorrhizal fungi and their distribution patterns related to host-plant sand habitats in a hot and arid ecosystem, southwest China. FEMS Microbiol. Ecol. 71, 418-427.

28. Lugo, M.A.; Cabello, M.N. (2002). Native arbuscular mycorrhizal (AMF) from mountain grassland (Córdoba, Argentina) I. Seasonal variation of fungal spore diversity. Mycologia 94, 579-586.

29. Lugo, M.A.; Maza, M.E.G.; Cabello, M.N. (2003). Arbuscular mycorrhizal fungi in a mountain grassland II. Seasonal variation of colonization studied, along with its relation to grazing and metabolic host type. Mycologia 95, 407-415.

30. Miller, R.M.; Reinhardt, D.R.; Jastrow, J.D. (1995). External hyphal production of vesicular-arbuscular mycorrhizal fungi in pasture and tallgrass prairie communities. Oecologia 103, 17-23.

31. Mullen, R.B.; Schmidt, S.K. (1993). Mycorrhizal infection, phosphorus uptake and phenology in Ranunculus adoneus: implications for the functioning of mycorrhizae in alpine systems. Oecologia 94, 229-234.

32. Muthukumar, T.; Udaiyan, K. (2002). Seasonality of vesicular-arbuscular mycorrhizae in sedges in a semi-arid tropical grassland. Acta Oecol. 23, 337-347.

33. Oliveira, A.N., Oliveira, L.A. (2005). Seasonal dynamics of arbuscular mycorrhizal fungi in plants of Theobroma grandiflorum Schum and Paullinia cupana Mart. of an agroforestry system in Central Amazonia, Amazonas State, Brazil. Braz. J. Microbiol. 36, 262-270.
34. Pearson, J.N.; Abbott, L.K.; Jasper, D.A. (1993). Mediation of competition between two colonizing VA mycorrhizal fungi by the host plant. New Phytol. 123, 93-98.

35. Rodríguez-Echeverría, S.; Hol, W.H.G.; Freitas, H.;Eason, W.R.; Cook, R. (2008). Arbuscular mycorrhizal fungi of Ammophila arenaria (L.) Link: Spore abundance and root colonisation in six locations of the European coast. Eur. J. Soil Biol. 44, 30-36.

36. Santos, J.C.; Finlay, R.D.; Tehler, A. (2006). Molecular analysis of arbuscular mycorrhizal fungi colonising a semi-natural grassland along a fertilisation gradient. New Phytol. 172, 159-168.

37. Schenck, N.C.; Pérez, Y. (1988). Manual for Identification of Vesiculararbuscular Mycorrhizal Fungi. 2nd edn. INVAM. University of Florida, Gainesville, Fla, USA.

38. Shannon, C.E.; Weaver, W. (1949). A Mathematical Model of Communication. University of Illinois Press, Urbana, IL.

39. Smith, F.A.; Smith, S.E. (1989). Membrane transport at the biotroph interface: an overview. Aust. J. Plant Physiol. 16, 33-43.

40. Smith, S.E.; Read, D.J. (2008). Mycorrhizal Symbiosis. 3rd edn. Academic Press, London.

41. Stümer, S.L.; Beller, M.M. (1994). Composition and seasonal variation of spore population of arbuscular mycorrhizal fungi in dune soils on the island of Santa Catarina, Brazil. Can. J. Bot. 72, 359-363.

42. Su, Y.Y.; Guo, L.D. (2007). Arbuscular mycorrhizal fungi in non-grazed, restored and over-grazed grassland in the Inner Mongolia steppe. Mycorrhiza 17, 689-693.

43. Umbanhowar, J.; McCann, K. (2005). Simple rules for the coexistence and competitive dominance of plants mediated by mycorrhizal fungi. Ecol. Lett. 8 (3), 247-252.

44. van der Heijden, M.G.A.; Boller, T.; Wiemken, A.; Sanders, I.R. (1998). Different arbuscular mycorrhizal fungal species are potential determinants of plant community structure. Ecology 79 (6), 2082-2091.

45. Vogelsang, K.M.; Reynolds, H.L.; Bever, J.D. (2006). Mycorrhizal fungal identity and richness determine the diversity and productivity of a tallgrass prairie system. New Phytol. 172 (3), 554-562. 